\title{
JUURNAL.RU
}

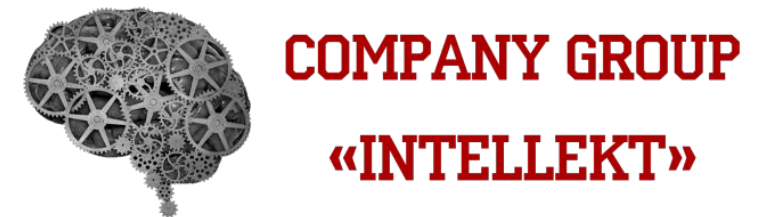

Томарева Е.И. Тульский государственный университет Тула, Россия

doi: 10.18411/lj2016-3-100

\section{Проведение пренатальной диагностики в Тульской области}

Современная пренатальная диагностика является обязательной частью национальной программы выявления наследственной и врожденной патологии плода-новорожденного и представлена на раннем сроке беременности ультразвуковым исследованием, материнским сывороточным скринингом на PAPP-A, b-HCG и последующими инвазивными методиками определения наследственных нарушений плода.

Целью настоящего исследования явилось изучение результативности пренатальной диагностики в Тульской области.

Объектом исследования послужили беременные женщины Тульской области, обследовавшиеся в медико-генетическом центре Тульского областного перинатального центра в 2013-2014 гг. Данные для анализа получены методом выкопировки из первичной медицинской документации медико-генетического центра.

Наиболее информативные тесты при определении хромосомной патологии плода проводятся на сроке 11-14 недель беременности. С 11 до 12 недель обследовано 10,8\% женщин, с 12 до 13 - 28,7\%, с 13 до 14 (13 недель 6 дней) $56,8 \%$ беременных. Срок определялся по копчико-теменному размеру, который составил от 40 до 50 мм у 4,1\% женщин, от 50 до 60 мм у 16,4\%, от 60 до 70 мм у $26,0 \%$, от 70 до 80 - у $42,5 \%$ и больше 80 мм у 10,1\% беременных. 
Для диагностики хромосомной патологии плода наиболее важное значение имеют результаты анализов PAPP-A и b-HCG, а также определение по ультразвуковому исследованию толщины воротникового пространства (ТВП) и носовой кости (НК) плода. Фактором риска является увеличение ТВП более 2,5 мм, что было установлено 19,2\% беременных, а отсутствие или гипоплазия НК плода наблюдалась у $43,1 \%$ женщин.

Диагностическая значимость PAPP-A и b-HCG в определении хромосомной патологии плода оптимальна на 11-14 неделе беременности в зависимости от отклонения от медианы на соответствующем сроке беременности. В группу риска попадают женщины, у которых значение РАРP-А в сыворотке крови менее 0,5 MOM (13,9\% обследуемых) или более 2,0 МОМ $(19,4 \%$ женщин). Аналогично первому показателю, у $16,7 \%$ женщин наблюдается снижение содержание b-HCG ниже 0,5 MOM и у 4,2\% беременных увеличение данного показателя выше 2,0 МОМ.

По сумме проведенных исследований в программе Astraia высокий риск (более чем 1:100) синдрома Дауна у плода выявлен у 8,3 \% женщин, синдрома Патау - у 9,7\%, синдрома Эдвардса - у 47,2\% обследуемых. Удельный вес врожденных пороков развития, диагностированных в 1 триместре в указанной группе риска составил 9,0\%. После проведения кариотипирования у 18,2\% женщин обнаружена хромосомная патология и рекомендовано прерывание беременности по медицинским показаниям, что имеет существенное значение [1-3]. Вместе с тем, 59,4\% женщин из числа обследуемых отказались от проведения инвазивных пренатальных методов обследования плода.

Таким образом, пренатальная диагностика хромосомной и врожденной патологии плода в Тульской области является высокоэффективным и результативным методом исследования. 


\section{Литература:}

1. Павлов О.Г., Кононенко Н.И., Тюрина Г.Л., Мандрик И.А., Тетерина С.П., Кононова М.В., Ржевкина Н.Н. Инвазивная пренатальная диагностика в практике Курской областной медико-генетической консультации // Медицинская генетика. 2005. Т. 4. № 5. С. 245.

2. Павлов О.Г. Прикладные вопросы ситуационного управления в социальномедицинской сфере. Старый Оскол: ТНТ, 2009. 276 с.

3. Павлов О.Г. Сочетанная соматическая патология родителей и репродуктивная функция их дочерей // Вестник новых медицинских технологий. 2011. Т. 18. № 3. С. 248-250. 